\title{
Variability in the trophic position of larval fishes in the upper Paraná floodplain based on $\delta^{15} \mathbf{N}$
}

\author{
GISLAINE I. MANETTA ${ }^{1}$, ANDRÉA BIALETZKI ${ }^{2}$, LUIZ A. MARTINELLI ${ }^{3}$ and EVANILDE BENEDITO ${ }^{2}$ \\ ${ }^{1}$ Curso de Pós-graduação em Ecologia de Ambientes Aquáticos Continentais \\ Universidade Estadual de Maringá, Av. Colombo, 5790, 87020-900 Maringá, PR, Brasil \\ ${ }^{2}$ Curso de Pós-graduação em Ecologia de Ambientes Aquáticos Continentais, Núcleo de Pesquisas em Limnologia, \\ Ictiologia e Aquicultura, Universidade Estadual de Maringá, Av. Colombo, 5790, 87020-900 Maringá, PR, Brasil \\ ${ }^{3}$ Centro de Energia Nuclear na Agricultura, Divisão de Funcionamento de Ecossistemas Tropicais, Laboratório de Ecologia \\ Universidade de São Paulo, Av. Centenário, 303, São Dimas, 13400-000 Piracicaba, SP, Brasil
}

Manuscript received on June 22, 2009; accepted for publication on September 2, 2010

\begin{abstract}
The upper Paraná River floodplain is composed of several marginal lagoons, making it a natural breeding ground for many fish species at developmental stages. The aim of this study is to estimate the trophic positions of these fishes based on feed intake (measured via diet) and nitrogen assimilation (measured via $\delta^{15} \mathrm{~N}$ ). The monthly samplings were concentrated during the spawning season in the Ivinheima River, which is located in the upper Paraná River floodplain. The specimens were grouped into preflexion, flexion and postflexion stages. Trophic positions were estimated based on the isotope value of nitrogen and on diet. During the developmental stages of $P$. squamosissimus, there were significant differences in the isotope values of $\delta^{15} \mathrm{~N}$; for $H$. edentatus, however, no significant differences were found. During the developmental stages, both species were classified as either at or above the third trophic level. Once this information is obtained for other species and components of the ecosystem, it will not only provide a more precise view of the energy allocation and flow in the ecosystem, but will also make possible for management measures to promote sustainability in this environment.
\end{abstract}

Key words: fish, larval development, trophic position, $\delta^{15} \mathrm{~N}$.

\section{INTRODUCTION}

In several fish species, changes in prey selection often result from ontogenic changes such as in the digestive tract morphology of larvae. Prey selection by fish larvae is affected by a preference for the most abundant items in the environment and prey size, which is associated with the size of the opening of the mouth (Makrakis et al. 2005). During development, the growth of larvae leads to tissue replacement, indicating the nitrogen isotope value of their new diet (Vander Zanden et al. 1998, Grey 2001, Gorokhova et al. 2005).

The analysis of fractionated nitrogen isotopes

Correspondence to: Evanilde Benedito

E-mail: eva@nupelia.uem.br along the food chain permits inferences regarding the trophic position of consumers, as opposed to the usual techniques for the study of diets (observation of food selection and/or analysis of stomach contents). Based on the isotopic composition of tissues in consumers, the precise indication is obtained by the assimilated item among those ingested (Fry and Arnold 1982). Stable nitrogen isotopes $\left(\delta^{15} \mathrm{~N}\right)$ are enriched 2 to $4 \%$ from prey to predator (Deniro and Epstein 1981, Minagawa and Wada 1984, Pinnegar and Polunin 1999, McCuthan Jr. et al. 2003) such that the $\delta^{15} \mathrm{~N}$ values of consumers can be compared to those of producers at the bottom of the food chain to provide a quantitative and reliable measurement of the trophic position of organisms (Vander Zanden and Rasmussen 1999). 
The upper Paraná River floodplain features a fauna that is highly adapted to the marked seasonal changes in biotic and abiotic factors imposed by the flood conditions. This environment presents abundant food and is recognized as a natural habitat for many different species of fish. The Ivinheima River sub-basin is formed by several marginal lagoons, making it an ideal habitat for the spawning and development of larvae of several fish species (Agostinho et al. 2004). A lot of studies have analyzed the nitrogen isotope variability and the trophic position of specific species of adult fishes in the upper Paraná River floodplain (A.C. Lopes, unpublished data, Manetta et al. 2003), but the trophic levels occupied by freshwater fish larvae during development have not yet been investigated.

According to studies conducted in the Itaipu floodplain and reservoir (Hahn et al. 1997a), Plagioscion squamosissimus is considered a piscivore, whereas $H$. edentatus is a planktivorous species (Lansac-Tôha et al. 1991, Hahn et al. 1997b), and these species are the most abundant in the samples gathered during the study. To better understand the energy flux in the Paraná River floodplain, this work investigated the fish species $P$. squamosissimus and $H$. edentatus with the aim of (1) identifying the intraspecific variations in isotope values during the developmental stages of these species, and (2) estimating their trophic positions based on feed intake (diet) and nitrogen assimilation $\left(\delta^{15} \mathrm{~N}\right)$.

\section{MATERIALS AND METHODS}

Samples were collected monthly during two spawning seasons: from October 2003 to March 2004, and from October 2004 to March 2005 (Nakatani et al. 2001). The samples were obtained from the Ivinheima River sub-basin located in the state of Mato Grosso do Sul, in the upper Paraná River floodplain, using a conic-cylindrical plankton net in nightly cycles with four-hour intervals among samplings.

The fish larvae were counted and identified by species. The most abundant species were Plagioscion squamosissimus (Heckel 1840) and Hypophthalmus edentatus (Spix 1829). The specimens were grouped together according to their level of notochord development into preflexion (PF), flexion (F) and postflexion (PoF) stages. For P. squamosissimus, nine samples each were collected in the preflexion and postflexion stages, and ten were collected in the flexion stage. For H. edentatus, the analysis consisted of three samples in the preflexion stage, six in the flexion stage and four in the postflexion stage.

To determine the isotope values, it was necessary to group between eight and ten individuals per sample. The stomach contents were removed from each individual to prevent the isotopic composition of the ingested items from interfering with those assimilated into the tissue of the analyzed fish.

The specimens were fixed in $70 \%$ alcohol and rinsed in distilled water to remove the excess alcohol. The samples were dried at $60^{\circ} \mathrm{C}$ and ground in a ball mill until they became fine powders. All samples were sent to the Center for Nuclear Energy in Agriculture (CENA) to determine the nitrogen isotope ratios using a mass spectrometer. Based on a study by Manetta and Benedito (in press) that used the same species in the adult phase, the isotopic results for these samples were corrected by subtracting $0.5 \%$. This correction factor has also been used by Vander Zanden et al. (2000) and Pease et al. (2006) for several species of fishes in the adult and larval stages, respectively.

A stochastic sampling of the stomachs was conducted using the Biostatistics Program with random larvae sampling and without repositioning. For diet analysis, 113 individuals of $P$. squamosissimus and 81 individuals of $H$. edentatus were used, distributed among the preflexion, flexion and postflexion stages.

The total stomach contents of the larvae from the preflexion and flexion stages were analyzed; only $2 / 3$ of the digestive tract from the samples of the postflexion stage were analyzed due to the accentuated level of digestion of food items in the final portion of this organ. The frequencies of occurrence of food items by developmental stage were calculated using the frequency of occurrence method (Hynes 1950).

\section{Trophic Position OF Fish LARVAE}

The trophic position based on the nitrogen isotope value $\left(\mathrm{PT}_{\delta 15 \mathrm{~N}}\right)$ was determined for each species according to the method of Vander Zanden et al. (1997):

$$
\mathrm{PT}_{\delta 15 \mathrm{~N}}=\left(\left(\delta^{15} \mathrm{~N}_{\text {fish }}-\delta^{15} \mathrm{~N}_{\text {source }}\right) / 2.3\right)+1
$$


where $\delta^{15} \mathrm{~N}_{\text {fish }}=$ the mean value of $\delta^{15} \mathrm{~N}$ for the developmental stages of the species; $\delta^{15} \mathrm{~N}_{\text {source }}=$ the mean value of $\delta^{15} \mathrm{~N}$ from allochthonous and autochthonous sources; 2.3 = fraction per trophic level (McCuthan Jr. et al. 2003); and $1=$ one level above the producers. The mean isotope value for ${ }^{15} \mathrm{~N}_{\text {source }}$ of allochthonous and autochthonous sources (phytoplankton, riparian vegetation, $\mathrm{C}_{3}$ and $\mathrm{C}_{4}$ macrophytes and periphyton) was $3.5 \%$.

The mean trophic position for each species as determined by diet $\left(\mathrm{PTM}_{\mathrm{d}}\right)$ was estimated using the formula of Vander Zanden et al. (1997):

$$
\mathrm{PTM}_{\mathrm{d}}=\Sigma\left(\mathrm{C}_{\mathrm{i}} \times \mathrm{T}_{\mathrm{i}}\right)+1
$$

where $C_{i}=$ contribution of food item $i ; T_{i}=$ trophic position of food item $\mathrm{i}$; and $1=$ one trophic level above the producers.

To calculate the trophic position using diet, food items were grouped (Vander Zanden et al. 1997) to assume a trophic position of 1 for algae, 2.5 for cladocera, copepods, insect pupae and larvae, and 3.0 for Chaoborus.

Isotopic differences among the developmental stages of fish larvae were investigated using an analysis of variance (non-parametric) Kruskal-Wallis model, Statistica 7.1 (Stat Soft Inc. 2005).

\section{RESULTS}

ONTOGENIC VARIATION OF $\delta^{15} \mathrm{~N}$

For $P$. squamosissimus, the mean nitrogen isotope values significantly increased $(\mathrm{H}=7.09 ; \mathrm{p}<0.05)$ as the larvae developed from preflexion $(8.3 \%)$ to flexion $(8.6 \%)$ and, finally, to postflexion $(8.7 \%)$ stages. It should be noted that there was a wider range of isotope variation during the first stage of larval development (Fig. 1).

Significant differences were found among the isotope values of $\delta^{15} \mathrm{~N}(\mathrm{H}=7.09 ; \mathrm{p}<0.05)$ during the different developmental stages.

The mean nitrogen values for $H$. edentatus did not significantly increase $(\mathrm{H}=3.67 ; \mathrm{p}>0.05)$ with ontogenic development; the values during the preflexion stage $(8.1 \%)$ remained close to those calculated for the flexion stage $(8.2 \%)$, and the mean value observed during the postflexion stage was the lowest $(7.9 \%)$ (Fig. 2).
No significant differences were identified $(\mathrm{H}=$ $3.67 ; \mathrm{p}>0.05$ ) in the isotope values for ${ }^{15} \mathrm{~N}$ among the developmental stages.

\section{TROPHIC POSITION}

The food items ingested during the different stages of development of both species consisted of algae, copepods, cladocera, detritus, insect larvae and pupae, and the carnivorous Chaoborus sp. (Table I). Detritus, larvae, pupae, and Chaoborus were observed only in the stomach contents of P. squamosissimus in small percentages during the flexion and preflexion stages.

The trophic positions calculated for P. squamosissimus and H. edentatus were situated in the third trophic level. For both species of larvae, the values of the calculated trophic positions based on diet composition $\left(\mathrm{PTM}_{\mathrm{d}}\right)$ and $\delta^{15} \mathrm{~N}\left(\mathrm{PT}_{\delta 15 \mathrm{~N}}\right)$ increased as the larvae changed stages (Fig. 3A, B). Values for $\mathrm{PTM}_{d}$ were lower than for $\mathrm{PT}_{\delta 15 \mathrm{~N}}$ during the preflexion and flexion stages of $P$. squamosissimus, and higher during the postflexion stage and for H. edentatus (Fig. 3A, B).

\section{DISCUSSION}

In the present study, the ontogenic variation in $\delta^{15} \mathrm{~N}$ as a result of diet composition was found in P. squamosissimus. During the preflexion stage of this species, a greater intake of algae was found relative to later developmental stages. In spite of the low diversity of ingested items during the preflexion stage, greater nitrogen isotope variability was observed. This could be a result of the combined isotope value derived from the onset of exogenous feeding and the parent isotope value (Vander Zanden et al. 1998) and/or the lipid reserve of the egg (Lesage et al. 2001). This can generate an increase in isotope variability, causing errors in the identification of the real assimilated food items and, consequently, the trophic position.

The mean isotope values of the flexion and postflexion stages for P. squamosissimus were increased relative to preflexion stages. During these same stages of larval development, an increase was observed in the frequency of occurrence of zooplankton (Cladocera and Copepoda), and benthic macroinvertebrates in diet were observed. This is likely related to the growth of the individual, which leads to an improvement in its natatory 


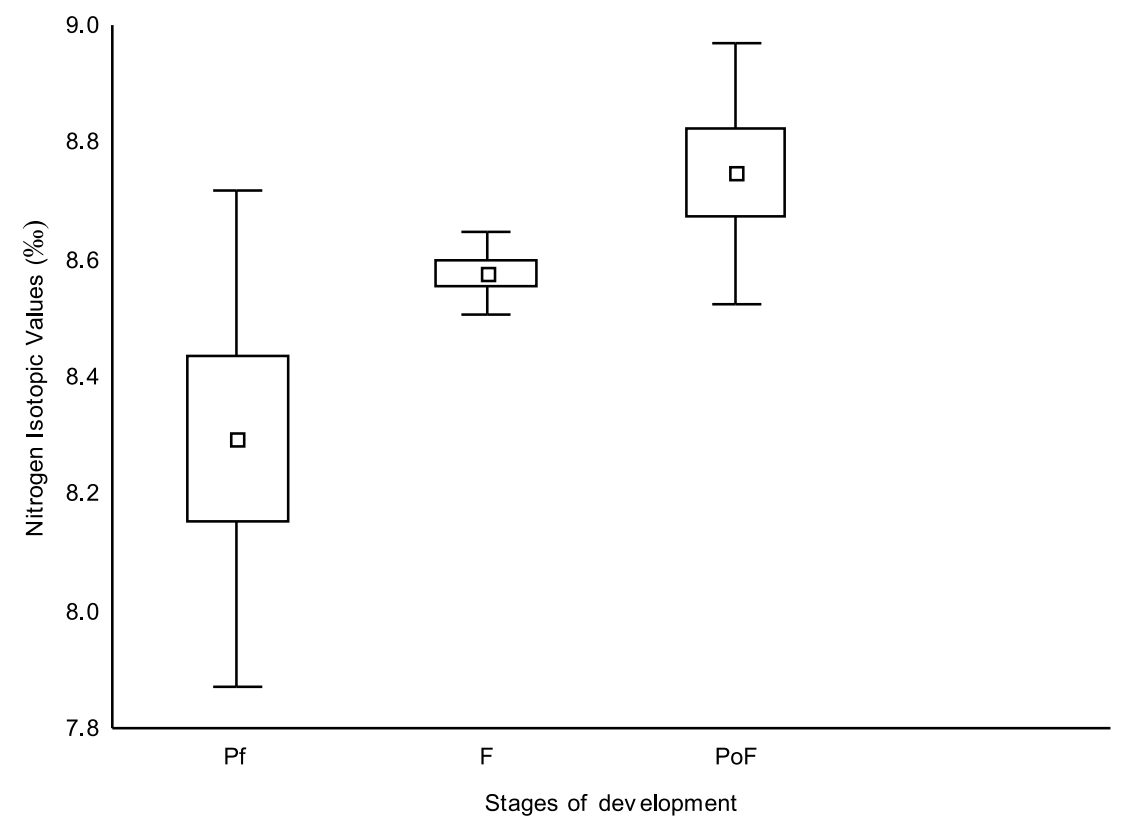

Fig. 1 - Mean values, standard error and standard deviation of the nitrogen isotope samples during the preflexion (Pf), flexion (F) and postflexion (PoF) stages of Plagioscion squamosissimus larval development.

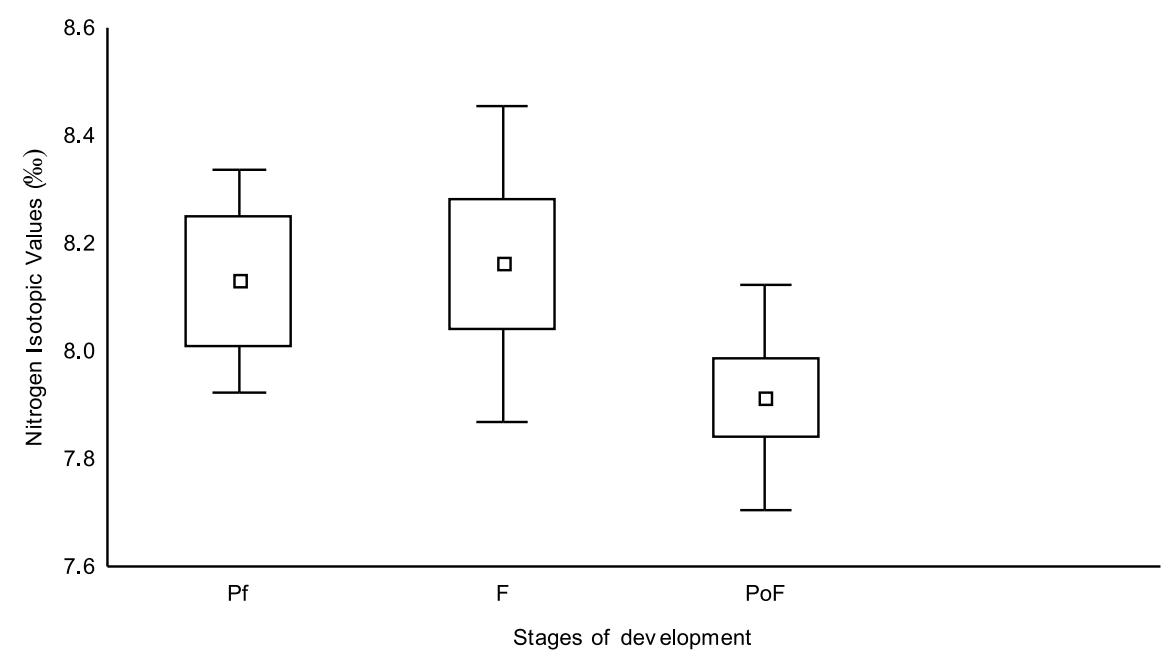

Fig. 2 - Mean values, standard error and standard deviation of the nitrogen isotope samples during the preflexion (Pf), flexion (F) and postflexion (PoF) stages of Hypophthalmus edentatus larval development.

ability and food capture besides the increase in mouth size, among other morphological changes (Makrakis et al. 2005). This result was also observed by Vander Zanden et al. (1998) and Grey (2001), who identified the association between larval growth and increase in $\delta^{15} \mathrm{~N}$ for the larvae of Micropterus dolomieu and Sal- mo trutta L., respectively. Conversely, no ontogenic alterations were observed in nitrogen isotope values and diet composition for H. edentatus. The diet of this species consisted of algae and cladocera during all stages of development. The absence of significant differences in nitrogen isotope values throughout development was 
TABLE I

Number of $\boldsymbol{P}$. squamosissimus and $\boldsymbol{H}$. edentatus stomachs analyzed $(\mathrm{N})$, and the frequency of occurrence of food items in diet separated by developmental stages (al - algae; $\mathbf{c}$ - copepods; cl-cladocera; d - detritus; li - insect larvae/pupae; ch - Chaoborus sp.).

\begin{tabular}{lcl}
\hline & $\mathrm{N}$ & Frequency of occurrence \\
\hline $\begin{array}{l}\text { P. squamosissimus } \\
\text { Preflexion }\end{array}$ & 25 & $30 \% \mathrm{al} ; 53 \% \mathrm{cl} ; 17 \% \mathrm{c}$ \\
Flexion & 30 & $22 \% \mathrm{al} ; 40 \% \mathrm{cl} ; 33 \% \mathrm{c} ; 2 \% \mathrm{~d} ; 3 \% \mathrm{ch}$ \\
Postflexion & 30 & $9 \% \mathrm{al} ; 60 \% \mathrm{cl} ; 24 \% \mathrm{c} ; 3 \% \mathrm{li} ; 4 \% \mathrm{ch}$ \\
H. edentatus & & \\
Preflexion & 24 & $21 \% \mathrm{al} ; 79 \% \mathrm{c}$ \\
Flexion & 32 & $17 \% \mathrm{al} ; 83 \% \mathrm{c}$ \\
Postflexion & 25 & $14 \% \mathrm{al} ; 86 \% \mathrm{c}$ \\
\hline
\end{tabular}

(A)

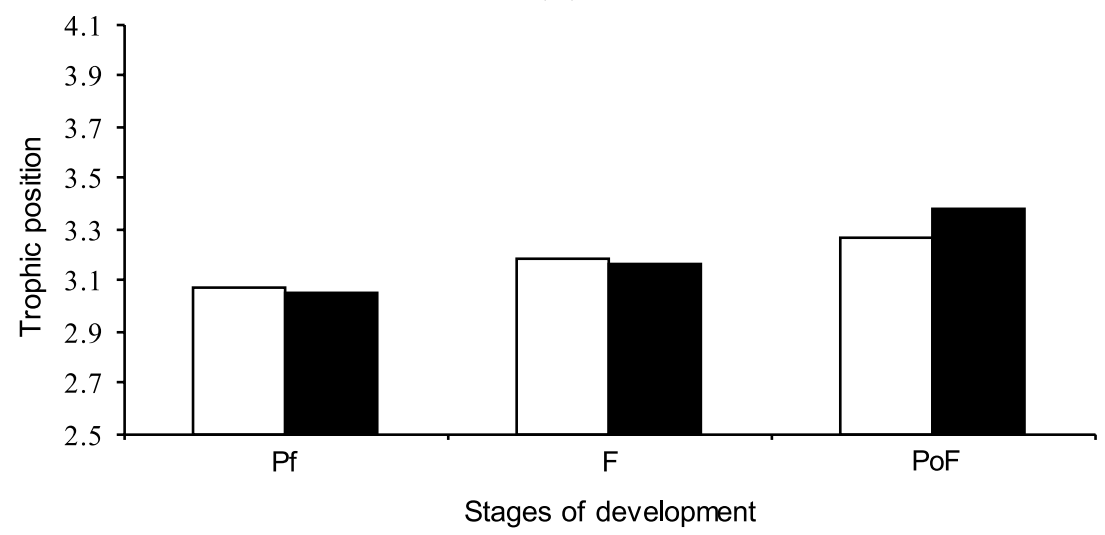

(B)

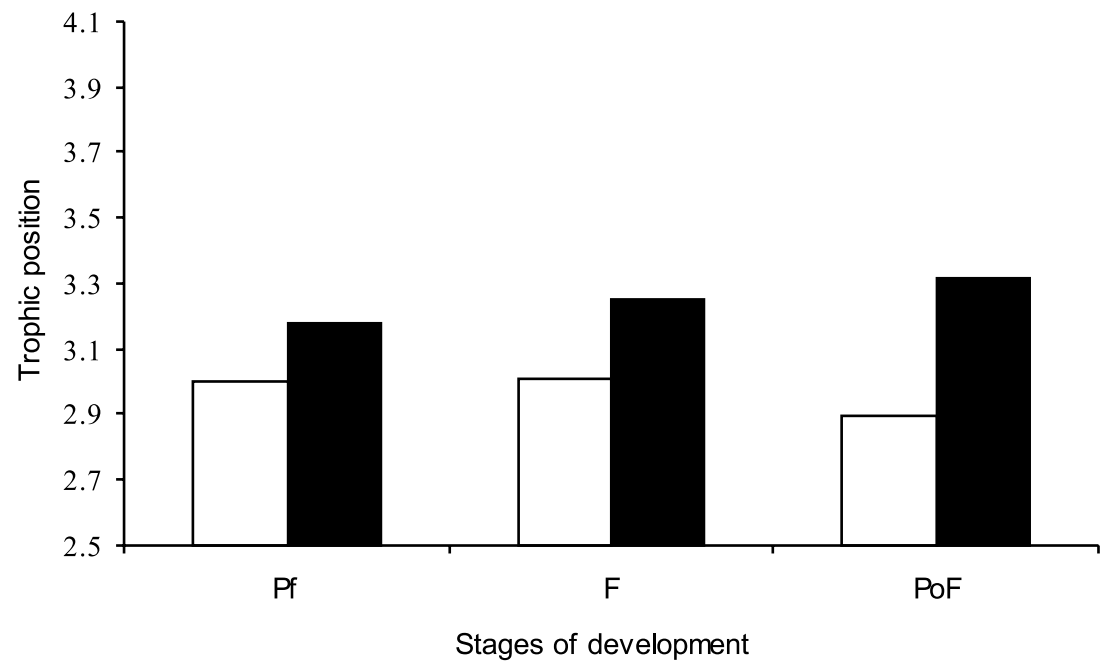

Fig. 3 - Trophic position calculated using nitrogen isotope value $(\square)$ and diet $(\square)$ during the preflexion (Pf), flexion (F) and postflexion (Pof) stages of Plagioscion squamosissimus (A) and Hypophthalmus edentatus (B) larval development. 
the result of the low diversity of items ingested by the species. These results corroborated the observations of $\mathrm{Gu}$ et al. (1997) who confirmed that the variability in ${ }^{15} \mathrm{~N}$ is small within a fish population with a single food source. Herzka et al. (2001) did not observe any relationship between larval development and alterations in ${ }^{15} \mathrm{~N}$ concentrations for food source.

For H. edentatus, an increase was observed in the trophic position values $\left(\mathrm{PTM}_{\mathrm{d}}\right.$ and $\left.\mathrm{PT}_{\delta 15 \mathrm{~N}}\right)$ throughout development, with the exception of $\mathrm{PT}_{\delta 15 \mathrm{~N}}$ in the postflexion stage. The lower value of the trophic position in the postflexion stage may be related to planktivorous feeding habits and the filter-feeding mechanism, which occur during the juvenile stage of this species (Makrakis et al. 2005) as a result of alterations in the gill rakers, which develop more rapidly during this stage and are longer and more numerous in the first branchial arch, decreasing in size and number toward the fourth branchial arch. According to Gerking (1994), all filtering species undergo changes in their food acquisition methods between the larval and adult stages. Initially, the larvae are predators, and their filtration mechanisms develop with the increasing of the body size. The transition from one feeding behavior to another is gradual, with an intermediate stage when the young fish feeds using both the particulate and the filter-feeding methods.

For the larvae of P. squamosissimus and H. edentatus, the trophic positions calculated by diet composition and $\delta^{15} \mathrm{~N}$, during the developmental stages were always close to the third trophic level. Leite et al. (2002) conducted studies in lagoons of the Amazon River floodplain on eight species of larvae from detrivorous and carnivorous fish and assigned them to the second and third trophic levels, indicating that fish larvae are primary carnivores during their initial stages of development regardless of their future trophic category as adults.

The association between the two methodologies employed in the present study for the investigation of food chains in neotropical ecosystems allows for greater accuracy in the definition of the ecological role of the different species that exist in the complex networks of trophic interactions. Nevertheless, many causes of variation identified in this study warrant further investigation. Studies describing the isotope variations associ- ated with invertebrates are still in their early stages and should shed light on the role of detritus and the microbial loop in the food chains of freshwater ecosystems. Once these gaps are filled, they will not only provide a more precise view of the energy allocation and flow in the ecosystem, but will also make possible for management measures to promote sustainability of environments that are severely threatened by anthropogenic impacts, as the case of floodplain areas.

\section{ACKNOWLEDGMENTS}

The authors thank the Núcleo de Pesquisas em Ictiologia, Limnologia e Aquicultura (NUPELIA), and Programa Ecológico de Longa Duração (PELD) for financial and logistic support; the Conselho Nacional de Desenvolvimento Científico e Tecnológico (CNPq) for making this project possible; and the entire team at NUPELIA's Laboratory of Energetic Ecology, Ichthyoplankton and Zooplankton.

\section{RESUMO}

A planície de inundação do alto rio Paraná é formada por várias lagoas marginais, tornando-se um criadouro natural de várias espécies de peixes nos estágios de desenvolvimento. O objetivo do estudo foi estimar as posições tróficas destes peixes, com base no alimento consumido (medido através dieta) e o nitrogênio assimilado (medido através $\delta^{15} \mathrm{~N}$ ). As amostragens mensais concentraram-se no período de desova das espécies, no rio Ivinheima, na planície de inundação do alto rio Paraná. Os espécimes foram agrupados em: pré-flexão, flexão e pósflexão. As posições tróficas foram estimadas com base no valor isotópico de nitrogênio e na dieta. Nas fases de desenvolvimento de P. squamosissimus houve diferença significativa nos valores isotópicos de $\delta^{15} \mathrm{~N}$, enquanto que, para $H$. edentatus, não foram identificadas. Ambas as espécies, durante os estágios de desenvolvimento, foram classificadas em igual ou acima do terceiro nível trófico. Estas informações, quando obtidas para outras espécies de peixes e componentes do ecossistema, fornecerão uma visão mais precisa da distribuição e fluxo de energia no ecossistema, além de tornar possível medidas de manejo, que visem promover a sustentabilidade deste ambiente.

Palavras-chave: peixe, desenvolvimento larval, posição trófica, $\delta^{15} \mathrm{~N}$. 


\section{REFERENCES}

Agostinho AA, Rodrigues L, Gomes CL, Thomaz SM AND Miranda LE. 2004. Structure and functioning of the Paraná River and its floodplain. Maringá, Eduem, $275 \mathrm{p}$.

Deniro M AND EPSTEIN S. 1981. Influence of diet on the distribution of nitrogen isotopes in animals. Geochim Cosmochim Acta 42: 495-506.

Fry B AND ARnOld C. 1982. Rapid ${ }^{13} \mathrm{C} /{ }^{12} \mathrm{C}$ Turnover during growth of brown shrimp (Penaeus aztecus). Oecologia 54: 200-204.

Gerking SD. 1994. Larval feeding. In: Gerking SD. Feeding of fish. San Diego: Academic Press, 336 p.

Gorokhova E, Hansson S, Hoglander H And AnDERSEN MC. 2005. Stable isotopes show food web changes after invasion by the cladoceran Cercopagis pengoi in a Baltic Sea bay. Oecologia 143: 251-259.

GREY J. 2001. Ontogeny and dietary specialization in brown trout (Salmo trutta L.) from Loch Ness, Scotland, examined using stable isotopes of carbon and nitrogen. Ecol Freshw Fish 10: 168-176.

Gu B, Schelske LC AND Hoyer VM. 1997. Intrapopulation feeding diversity in blue tilapia: evidence from stable-isotope analyses. Ecology 78: 2263-2266.

Hahn NS, Agostinho AA And Goitein R. 1997a. Feeding ecology of curvina Plagioscion squamosissimus (Hechel, 1840) (Osteichthyes, Perciformes) in the Itaipu reservoir and Porto Rico floodplain. Acta Limnol Bras 9: 11-22.

Hahn NS, Andrian IF, Fugi R AND Almeida VLL. 1997b. Ecologia Trófica. In: VAZzoler AEAM, AGOSTINHO AA AND HAHN NS. A planície de inundação do rio Paraná: aspectos físicos, biológicos e socioeconômicos. Maringá, Eduem/Nupelia, p. 209-228.

HerzKa SZ, Holt SA And Joanholt G. 2001. Documenting the settlement history of individual fish larvae using stable isotope ratios: model development and validation. J Exper Mar Biol Ecol 265: 49-74.

HYNES HBN. 1950. The food of food freswater stickbacks (Gasterosteus aculeatus and Pigosteus pungitius), with a review of methods and their application. J Fish Biol 19: $36-56$.

LANSAC-TÔHA FA, LIMA AF, HAHN NS AND ANDRIAN IF. 1991. Composição da dieta alimentar de Hypophthalmus edentatus Spix, 1829 (Pisces, Hypophthalmidae) no reservatório de Itaipu e no rio Ocoí. Unimar 13: 147-162.
Leite RG, ARAÚJo-Lima MRAC, ViCTORIA LR AND MARTINelli AL. 2002. Stable isotope analysis of energy sources for larvae of eight fish species from the Amazon floodplain. Ecol Freshw Fish 11: 56-63.

Lesage V, Hammil MO And Kovacs KM. 2001. Marine mammals and the community structure of the Estuary and Gulf of St Lawrence, Canada: evidence from stable isotope analysis. Mar Ecol Prog Ser 210: 203-221.

Makrakis MC, NaKatani K, Bialetzki A, SAnches PV, Baumgartner G And Gomes LC. 2005. Ontogenetic shifts in digestive tract morphology and fish larvae of the Itaipu Reservoir, Brazil. Environ Biol Fishes 72: 99-107.

Manetta Gi, Benedito-Cecilio E And Martinelli AL. 2003. Carbon sources and trophic position of the main species of fishes of Baía river, Paraná river floodplain, Brazil. Braz J Biol 63: 283-290.

Manetta GI AND Benedito E (in press). Composição isotópica de ${ }^{13} \mathrm{C}$ e de ${ }^{15} \mathrm{~N}$ em músculos de peixes de água doce: efeito de conservantes. Acta Scientiarum.

McCuthan JR HJ, Lewis JR MW, Kendall C And MCGRATH CC. 2003. Variation in trophic shift for stable isotope ratios of carbon, nitrogen, and sulfur. Oikos 102: 378-390.

Minagawa M ANd WAdA E. 1984. Stepwise enrichment of ${ }^{15} \mathrm{~N}$ along food chains: further evidence and the relation between $\delta^{15} \mathrm{~N}$ and animal age. Geochim Cosmochim Acta 48: 1135-1140.

Nakatani K, Agostinho AA, Baumgartner G, BiaLeTZKi A, SANCHES PV, MAKRAKis CM AND PAVANELLi SC. 2001. Ovos e larvas de peixes de água doce: desenvolvimento e manual de identificação. Maringá, Eduem, 378 p.

Pease AA, Davis JJ, Edwards MS And Turner TF. 2006. Habitat and resource use by larval and juvenile fishes in an arid-land river (Rio Grande, New Mexico). Freshw Biol 51: 475-486.

PinNegar JK AND Polunin NVC. 1999. Differential fractionation of $\delta^{13} \mathrm{C}$ and $\delta^{15} \mathrm{~N}$ among fish tissues: implications for the study of trophic interactions. Ecology 13: $225-231$.

StATSoft InC. 2005. STATISTICA (data analysis software system), version 7.1. Www.statsoft.com.

VANDER ZANDEN MJ, CABANA G AND RASMussen JB. 1997. Comparing trophic position of freshwater fish calculated using stable nitrogen isotope ratios $\left(\delta^{15} \mathrm{~N}\right)$ and literature dietary data. Can J Fish Aquat Sci 54: 1142-1158. 
VANDER ZANDEN MJ, HULSHOF M, RIDGWAY MS AND

RASMUSSEN JB. 1998. Application of Stable isotope Techniques to Trophic Studies of Age-0 Smallmouth Bass. Trans Am Fish Soci 127: 729-739.

VANDER ZANDEN MJ AND RASMUSSEn BJ. 1999. Primary consumer $\delta^{13} \mathrm{C}$ and $\delta^{15} \mathrm{~N}$ and trophic position of aquatic consumers. Ecology 80: 1395-1404.
VANDER ZANDEN MJ, SHUTER JB AND LESTER PN. 2000. Within- and among-population variation in the trophic position of a pelagic predator, lake trout (Salvelinus namaycush). Can J Fish Aquat Sci 57: 725-731. 